\title{
Development of a DNA microarray assay for rapid detection of fifteen bacterial pathogens in pneumonia
}

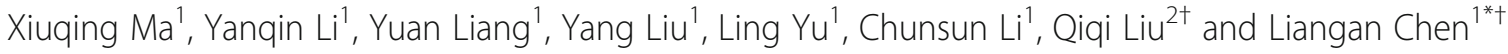

\begin{abstract}
Background: The rapid identification of pathogenic bacteria is important for determining an appropriate antimicrobial therapy for pneumonia, but traditional bacterial culture is time-consuming and labourious. The aim of this study was to develop and evaluate a DNA microarray assay for the simultaneous detection of fifteen bacterial species directly from respiratory tract specimens in patients with pneumonia. These species included Streptococcus pneumoniae, Staphylococcus aureus, Haemophilus influenzae, Escherichia coli, Klebsiella pneumoniae, Pseudomonas aeruginosa, Acinetobacter baumannii, Mycoplasma pneumoniae, Enterococcus faecalis, Enterococcus faecium, Enterobacter cloacae, Stenotrophomonas maltophilia, Burkholderia cepacia, Legionella pneumophila and Chlamydia pneumoniae. The $16 \mathrm{~S}$ rDNA genes and other specific genes of each pathogen were chosen as the amplification targets, amplified via multiplex polymerase chain reaction (PCR), and hybridized to oligonucleotide probes in a microarray.

Results: The DNA microarray detection limit was $10^{3}$ copies/ $\mu \mathrm{L}$. Nineteen standard strains and 119 clinical isolates were correctly detected with our microarray, and 3 nontarget species from 4 clinical isolates were not detected. Additionally, bacterial pathogens were accurately identified when two or three bacterial targets were mixed together. Furthermore, the results for $99.4 \%$ (156/157) of clinical specimens were the same as those from a conventional assay.

Conclusions: We developed a DNA microarray that could simultaneously detect various bacterial pathogens in pneumonia. The method described here has the potential to provide considerable labour and time savings due to its ability to screen for 15 bacterial pathogens simultaneously.
\end{abstract}

Keywords: DNA microarray, Bacteria, Pneumonia

\section{Background}

The rapid identification of pathogenic bacteria is important for selecting an appropriate antimicrobial therapy for pneumonia [1]. However, current standard microbiological culture-based tests are labourious and time consuming [2]. Patients often receive empirical broad-

\footnotetext{
*Correspondence: Chenliangan301@163.com

${ }^{\dagger}$ Qiqi Liu and Liangan Chen contributed equally to this work.

'Department of Pulmonary \& Critical Care Medicine, Chinese PLA General Hospital, Beijing, China

Full list of author information is available at the end of the article
}

spectrum antimicrobial treatment while waiting for microbiology results. Hence, novel diagnostic approaches are urgently needed to improve early antimicrobial therapy for pneumonia.

Standard European guidelines for the diagnosis and management of pneumonia note that molecular diagnosis is a promising method for rapidly detecting pathogens [3]. Several molecular methods based on polymerase chain reaction (PCR) have been developed to detect species-specific genes. Such methods have been developed for the identification of Pseudomonas aeruginosa by the amplification of

C The Author(s). 2020 Open Access This article is licensed under a Creative Commons Attribution 4.0 International License, which permits use, sharing, adaptation, distribution and reproduction in any medium or format, as long as you give appropriate credit to the original author(s) and the source, provide a link to the Creative Commons licence, and indicate if changes were made. The images or other third party material in this article are included in the article's Creative Commons licence, unless indicated otherwise in a credit line to the material. If material is not included in the article's Creative Commons licence and your intended use is not permitted by statutory regulation or exceeds the permitted use, you will need to obtain permission directly from the copyright holder. To view a copy of this licence, visit http://creativecommons.org/licenses/by/4.0/. The Creative Commons Public Domain Dedication waiver (http://creativecommons.org/publicdomain/zero/1.0/) applies to the data made available in this article, unless otherwise stated in a credit line to the data. 
the specific exotoxin A gene [4], the identification of $\mathrm{Myco-}$ plasma pneumoniae using a fragment of the gene encoding P1 cytadhesin protein [5], the identification of Haemophilus influenzae by amplifying a fragment of the gene encoding the P6 outer membrane protein [6], and many others [7]. However, these methods have a narrow diagnostic spectrum.

To address this problem, multiplex PCR or ribosomal DNA (rDNA) has been used [8-10]. Although multiplex PCR can simultaneously detect several different bacteria, the number of bacteria is still limited within a single test. $16 \mathrm{~S}$ rDNA sequences exist universally within bacteria and include both conserved regions and species-specific regions [11]. The most common method is to use a universal primer pair to amplify species-specific fragments of $16 \mathrm{~S}$ rDNA. However, it is not possible to achieve complete discrimination among some genera, such as Enterobacteriaceae, in which the $16 \mathrm{~S}$ rDNA sequences of Klebsiella pneumoniae, Enterobacter cloacae and Escherichia coli are very similar [12].

To extend the detection spectrum and shorten the detection time, we developed a DNA microarray assay that can detect 15 bacterial respiratory pathogens associated with pneumonia, including Streptococcus pneumoniae, Staphylococcus aureus, Haemophilus influenzae, Escherichia coli, Klebsiella pneumoniae, Pseudomonas aeruginosa, Acinetobacter baumannii, Mycoplasma pneumoniae, Enterococcus faecalis, Enterococcus faecium, Enterobacter cloacae, Stenotrophomonas maltophilia, Burkholderia cepacia, Legionella pneumophila and Chlamydia pneumoniae. To identify bacteria at the species level, we chose to use a $16 \mathrm{~S}$ rDNA probe combined with a species-specific probe to detect each bacterium. The sequences of the species-specific probes corresponded to 15 species-specific genes.

\section{Results}

\section{Primer design and evaluation}

Specific genes for the targeting of the 15 different bacterial species were selected based on a thorough literature search for particular bacterial housekeeping genes. The 15 bacterial-specific genes were lytA of Streptococcus pneumoniae [8], nuc of Staphylococcus aureus [8], P6 of Haemophilus influenzae [13], phoA of Escherichia coli [14], mdh of Klebsiella pneumoniae [14], toxA of Pseudomonas aeruginosa [4], gltA of Acinetobacter baumannii [14], P1 of Mycoplasma pneumoniae [5], ddl of Enterococcus faecalis and Enterococcus faecium [15], dnaJ of Enterobacter cloacae [16], chitA of Stenotrophomonas maltophilia [17], recA of Burkholderia cepacia [18], mip of Legionella pneumophila and ompA of Chlamydia pneumoniae $[5,19]$. We designed all primers in house. Three pairs of primers were initially designed for each specific gene, and the primer pairs were checked by BLAST searches (http://www.ncbi.nih.gov). If all 3 pairs of primers failed to be successfully amplified, we designed 3 alternative pairs of primers. After repeated screening, 16 pairs of primers, including one pair of universal $16 \mathrm{~S}$ rDNA primers and 15 pairs of bacterialspecific gene primers, were selected and successfully amplified (Table 1). All primers included in an individual group for multiplex asymmetric PCR presented a similar melting temperature. The specificity of the 16 paired primers was preliminarily tested by PCR, and the PCR products were examined by $2 \%$ agarose gel electrophoresis (Fig. S1). All primers and probes were finally confirmed by sequence analysis of the PCR products from the reference plasmids.

\section{The limit of detection and accuracy of the microarray}

The microarray layout is shown in Fig. 1a. The detection limit of each probe reached $10^{3}$ copies/ $\mu \mathrm{L}$ (Fig. 2). Positive diagnostic hybridization was confirmed only when three probes produced signals simultaneously. These three probes were the positive control probe from the conserved 16S rDNA sequence, the specific probe for the $16 \mathrm{~S}$ rDNA sequence each target bacterium and the specific probe for the specific gene of each target bacterium. A total of 138 strains, including 19 standard strains and 119 clinical isolates (Table 2), were correctly detected with our microarray (Fig. 1b). Three nontarget bacterial species from 4 isolates in the collection were not detected (Fig. 1b). The hybridization signals emerged in order at the position corresponding to each target genus or species from the bacterial cultures, and none of the probes showed cross-hybridization between the target pathogens. For the 2 Streptococcus viridans isolates, we observed that only the specific $16 \mathrm{~S}$ rDNA probe of Streptococcus spp. and the universal $16 \mathrm{~S}$ rDNA probe produced signals. For one Moraxella catarrhalis isolate and one Neisseria mucosa isolate, a hybridization reaction only appeared at the position of the universal $16 \mathrm{~S}$ rDNA probe. Furthermore, water was processed in parallel with the clinical samples as a negative PCR control, and the hybridization results showed no signal (Fig. 1b). In addition, all components within a mock specimen, which consisted of two or three target bacteria, could be accurately identified despite the presence of other components (Fig. 3a).

\section{Detection of clinical specimens}

Among the 157 clinical specimens, 105 specimens exhibited only one pathogen, 36 specimens exhibited two pathogens, 5 specimens exhibited three pathogens, and 11 specimens exhibited no pathogens (Table 3). First, 151 bacterial pathogens belonging to 10 target species in clinical samples were correctly identified by the microarrays according to the results of bacterial culture. Second, the identification of one specimen with the microarray 


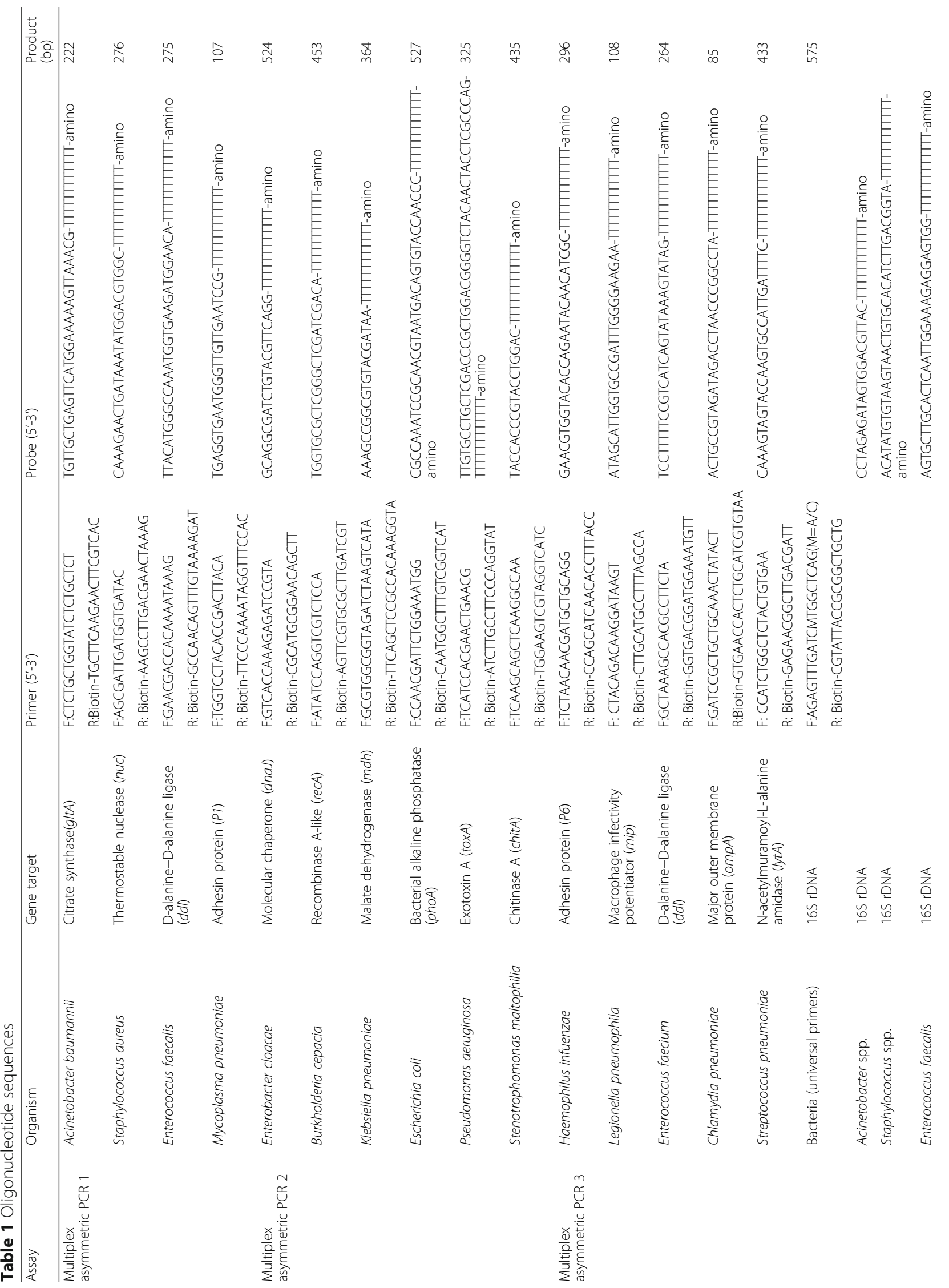




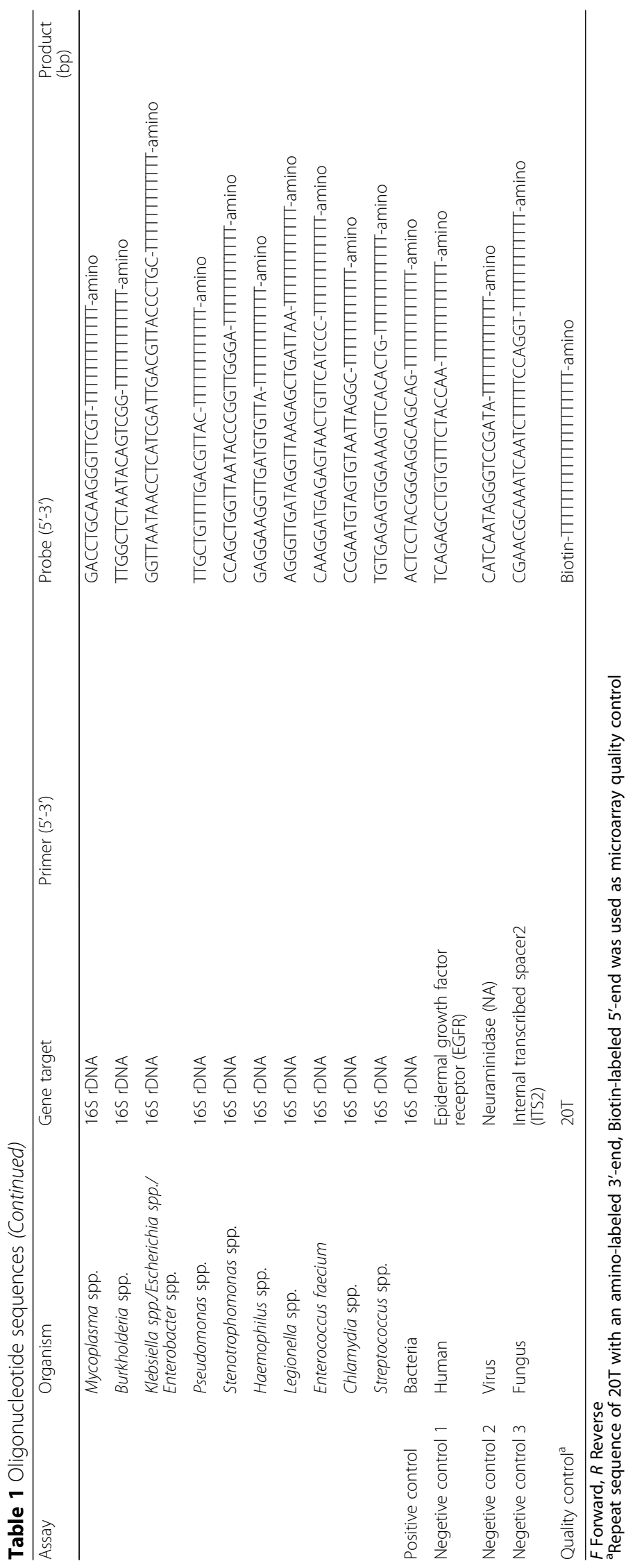




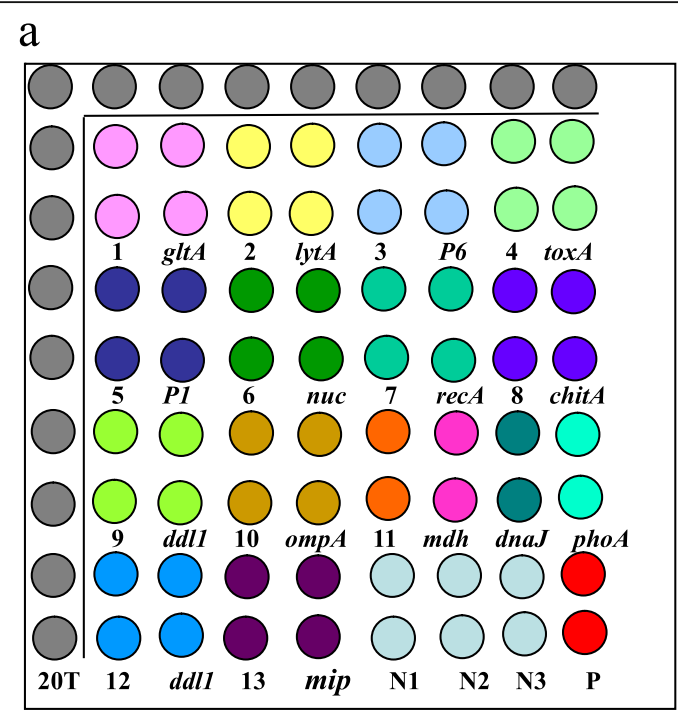

b
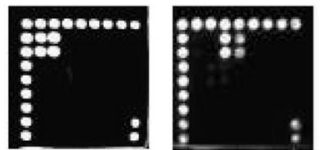

Acinetobacter Streptococcus

baumannii
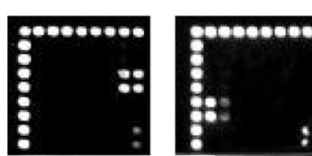

Stenotrophomonas

maltophilia

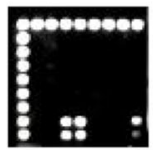

Legionella

pneumophila

faecalis

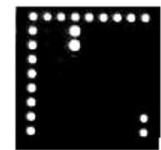

Streptococcus

viridans

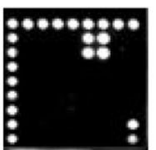

Haemophilus

influenzae

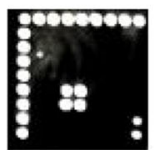

Chlamydia

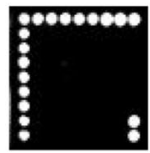

Moraxella

catarrhalis

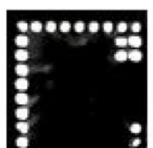

Pseudomonas Mycoplasma

aeruginosa

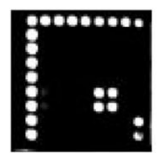

Klebsiella

pneumoniae pneumoniae

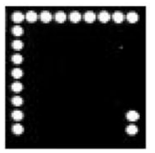

Neisseria

mucosa
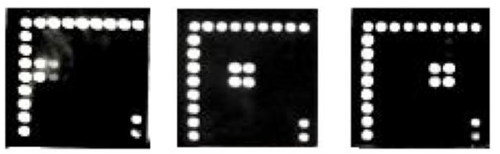

Staphylococcus Burkholderia

aureus

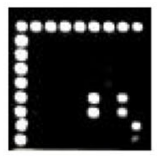

Enterobacter

cloacae

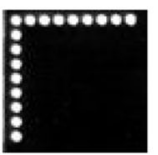

$\mathrm{ddH}_{2} \mathrm{O}$

Fig. 1 a. The layout of the hybridization capture-chip. The probe $20 \mathrm{~T}$ is the QC probe. The probe N1, N2, N3 are the negative control probes. The probe $\mathrm{P}$ is the universal $16 \mathrm{~S}$ rDNA probe. Each probe was spotted as two. The sequences of probe 1-13 all come from $16 \mathrm{~S}$ rDNA and their corresponding target pathogen were: 1 Acinetobacter baumannii; 2 Streptococcus pneumoniae; 3 Haemophilus influenzae; 4 Pseudomonas aeruginosa; 5 Mycoplasma pneumoniae; 6 Staphylococcus aureus; 7 Burkholderia cepacia; 8 Stenotrophomonas maltophilia; 9 Enterococcus faecalis; 10 Chlamydia pneumoniae; 11 Klebsiella pneumoniae or Enterobacter cloacae or Escherichia coli; 12 Enterococcus faecium; 13 Legionella pneumophila, respectively. b. The typical hybridization results of fifteen species of bacterial pathogens in pneumonia, non-target bacteria from pure bacterial cultures and $\mathrm{ddH} 2 \mathrm{O}$

differed from the bacterial culture results. In scanning images of this specimen from two assays, only probes for Acinetobacter baumannii and the universal 16S rDNA probe presented a signal; therefore, we deduced that the specimen contained Acinetobacter baumannii. Additionally, the results for three replicates in the PCR analysis of the specimen based on the specific nuc gene of Staphylococcus aureus were negative. Finally, the microarray results for 40 bacterial pathogens belonging to 8 nontarget species in clinical samples were negative (Table 3). However, for Streptococcus viridans, Staphylococcus hominis, Staphylococcus epidermidis and Staphylococcus haemolyticus, specific 16S rDNA probes for these bacteria and the universal $16 \mathrm{~S}$ rDNA probe exhibited signals, which indicated that this microarray could identify some nontarget bacteria at the genus level. For Neisseria mucosa, Chryseobacterium indologenes, Ralstonia mannitolilytica, and Citrobacter freundii, only 


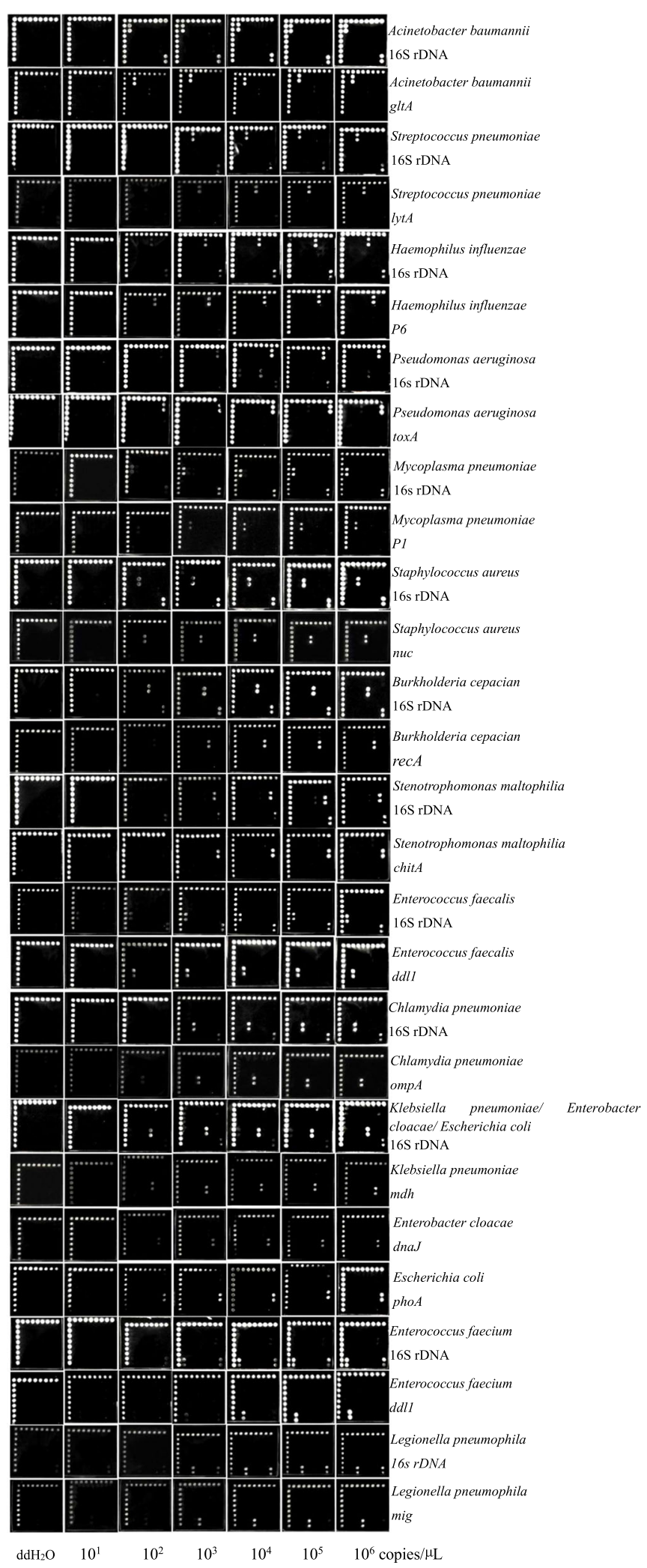

Fig. 2 The sensitivity of the pathogen probes. Microarray hybridized with PCR products which diluted for concentration gradient. $10 \mu \mathrm{L}$ dilution used in each well, and the concentration of probes were $50 \mu \mathrm{M}$ 


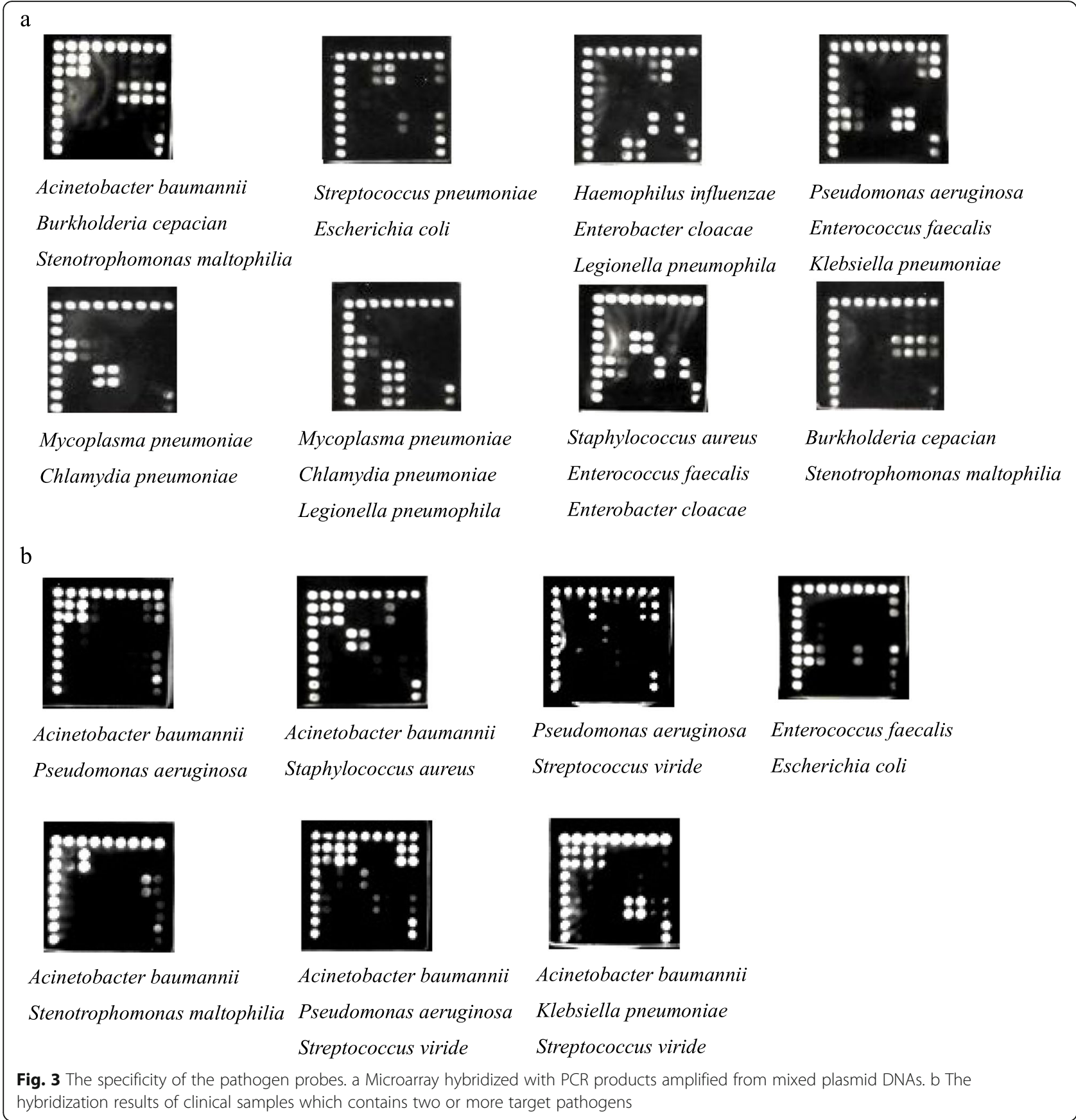

the universal 16S rDNA probe presented a signal, which demonstrated that this microarray could determine whether the specimens contained bacteria. The hybridization results for clinical samples containing two or more target pathogens are shown in Fig. $3 \mathrm{~b}$.

\section{Discussion}

We report the development of a novel DNA microarray for 15 important respiratory bacterial pathogens and the evaluation of its potential as a promising diagnostic tool for pneumonia. We employed two probes, one for a specific $16 \mathrm{~S}$ rDNA sequence and the other for a specific gene sequence, to identify each target bacterium. The detection limit of each probe reached $10^{3}$ copies $/ \mu \mathrm{L}$. The detection accuracy of the microarray for the clinical isolates and specimens reached 100 and 99.4\%, respectively.

A particular strength of our study was that this microarray simultaneously uses a genus-specific probe and species-specific probe to detect targeted bacteria. In recent years, DNA microarrays have been developed to identify bacteria in lung diseases, but they can detect no 
Table 2 Reference strains used in this study

\begin{tabular}{|c|c|c|}
\hline Organism & No. & Source/strain \\
\hline \multicolumn{3}{|l|}{ Target species } \\
\hline Acinetobacter baumannii & 25 & ATCC19606; clinical isolates (24) \\
\hline Pseudomonas aeruginosa & 22 & ATCC27853; clinical isolates (21) \\
\hline Klebsiella pneumoniae & 22 & ATCC700603; clinical isolates (21) \\
\hline Enterococcus faecium & 17 & ATCC35667; clinical isolates (16) \\
\hline Escherichia coli & 13 & ATCC25922; clinical isolates (12) \\
\hline Enterococcus faecalis & 12 & ATCC29212; clinical isolates (11) \\
\hline Mycoplasma pneumoniae & 5 & ATCC29342; clinical isolates (4) \\
\hline Streptococcus pneumoniae & 4 & ATCC49619; CMCC31001; clinical isolates (2) \\
\hline Staphylococcus aureus & 4 & ATCC25923; N315; clinical isolates (2) \\
\hline Stenotrophomonas maltophilia & 4 & CGMCC1.1788; clinical isolates (3) \\
\hline Burkholderia cepacia & 3 & CGMCC1.1813; clinical isolates (2) \\
\hline Haemophilus infuenzae & 3 & ATCC9006(serotypeA); ATCC33533(serotypeB); ATCC9007(serotypeC) \\
\hline Enterobacter cloacae & 2 & ATCC13047; clinical isolate \\
\hline Legionella pneumophila & 1 & ATCC33152 \\
\hline Chlamydia pneumoniae & 1 & ATCC VR1310 \\
\hline \multicolumn{3}{|l|}{ Non-target species } \\
\hline Streptococcus viridans & 2 & Clinical isolates \\
\hline Moraxella catarrhalis & 1 & Clinical isolate \\
\hline Neisseria mucosa & 1 & Clinical isolate \\
\hline
\end{tabular}

ATCC American Type Culture Collection, CMCC National Center for Medical Culture Collections, CGMCC China General Microbiological Culture Collection Center

more than two target genes: one species-specific gene [20] and one conserved gene, including rDNA genes and several phylogenetically conserved genes $[11,12,21]$. For the former, the number of detected bacteria is limited in a single test. For the latter, a single marker cannot achieve the unambiguous detection of closely related or distant species [22]. Therefore, the use of conserved bacterial genes combined with species-specific genes is necessary for the accurate diagnosis of bacteria. To the best of our knowledge, there are no other assays simultaneously using $16 \mathrm{~S}$ rDNA and bacterial species-specific genes for bacterial identification. Moreover, even when samples that contained bacteria not belonging to the fifteen target bacteria were analysed in this study, they could be identified at the genus level. This method might be a useful addition to the microarray technique.

Furthermore, this microarray could allow rapid bacterial identification directly from patient samples. First, the entire experimental procedure for this assay, from sample receipt to results dissemination, can be completed within $6 \mathrm{~h}$. This is much faster than current methods, most of which require an additional $18-24 \mathrm{~h}$ for the growth of bacteria in clinical practice. Second, these fifteen target bacteria cover the most common bacterial causes of community acquired pneumonia (CAP) and hospital acquired pneumonia (HAP) [23, 24], especially atypical pathogens, which are difficult to identify because of lengthy and complicated culture methods $[25,26]$. Finally, due to the high-throughput characteristics of the microarray, our microarray can simultaneously detect 15 pathogenic bacteria in one test. These timely and abundant identification results can facilitate the early administration of antimicrobial therapy for pneumonia and prevent bacterial resistance caused by empirical antibiotic therapy. This microarray is worthy of being recommended for use in clinical applications.

This assay was validated with 19 type strains, 119 clinical isolates belonging to 15 target species, 4 clinical isolates belonging to 3 nontarget species and 8 mixed mock specimens. Bacterial strains were cultured overnight in $5 \mathrm{ml}$ of species-specific culture medium and at the corresponding growth temperature. All cells were collected for DNA extraction, and $2.5 \mu \mathrm{L}$ of the DNA template was used for PCR in microarray validation. This number must be translated into the corresponding number of bacteria since a correction factor has to be introduced due to the extraction efficiency and sample dilution [21]. However, based on the correct identification of the 19 type strains, 119 clinical isolates belonging to 15 target species, 8 mixed mock specimens and 4 clinical isolates belonging to 3 nontarget species, the sensitivity and specificity were both $100 \%$, and the microarray could be concluded to be an efficient diagnostic method for clinical isolates. The criteria for the selection of clinical 
isolates belonging to nontarget species in this study were that they are often detected in respiratory tract specimens but in most cases are not the main pathogenic bacteria. We used only 4 clinical isolates belonging to 3 nontarget species, which is a small number. Nevertheless, the detection was found to be specific for the 19 type strains, 119 clinical isolates belonging to 15 target species, and 151 bacterial pathogens belonging to 10 target species in clinical samples, and this assay did not detect any of the 4 clinical isolates belonging to nontarget species and the 40 bacterial pathogens belonging to 8 nontarget species in clinical samples. We cannot exclude the possibility that other bacterial species in respiratory tract specimens would cause a reaction with the selected probes, thus interfering with detection. However, this probability is low given the very few cross-reactions observed for the 19 type strains, 123 clinical isolates and 191 bacterial pathogens in the clinical samples tested here.

In this study, the microarray results were compared with the culture results when the microarray effectiveness was assessed with clinical specimens. First, culture is still the most popular method and the gold standard for the identification of bacteria in clinical practice, even though it can produce both false-negative and falsepositive results. Second, the 157 clinical specimens tested in our study were collected before antibiotic therapy. Antibiotic therapy can reduce the bacterial burden and viability, potentially leading to negative culture results [27]. Moreover, 121 out of the 157 specimens were endotracheal aspirates and BALF specimens, which are often of better quality than expectorated sputum specimens [28, 29]. Therefore, these procedures prevented the occurrence of false negatives and false positives during bacterial culture to a certain degree. Third, a sequencing method was used to confirm the results when the culture and microarray results were discordant. In this study, the culture and microarray results were different for only one sputum sample. The culture result for this sample corresponded to both Staphylococcus aureus and Acinetobacter baumannii, whereas the microarray result showed only Acinetobacter baumannii, and the results of three replicates of PCR targeting the specific nuc gene of Staphylococcus aureus were negative. Thus, no specimens were sequenced. Finally, among the 15 bacterial species included in the microarray, 10 different species were found in the clinical samples, which are all relatively easy to identify by culture. Hence, this microarray method was compared with the conventional culture method.

The array was further assessed for its effectiveness in 157 clinical specimens from different patients. Polybacterial infections were well detected in 41 samples. Compared with the culture results, the specificity and sensitivity of the microarray were 100 and $99.4 \%$, respectively. An increased sensitivity of molecular methods based on PCR is reported [13, 30-32]. In this study, only Staphylococcus aureus in one sample was not detected by the microarray. The lower sensitivity might be attributable to the DNA extraction procedure or erroneous culture identification. In a recent study, in addition to the standard automated extraction protocol, the addition of proteinase $\mathrm{K}$ and lysostaphin was necessary for the efficient extraction of Staphylococcus aureus DNA from sputum samples, particularly mucopurulent samples [8, 33]. Unfortunately, no stored specimens could be re-extracted or re-cultured because all the specimens were used in the molecular analyses. Another reason for the lower sensitivity might be that the number of Staphylococcus aureus cell was sufficient for culture but was too low for detection with the microarray. The last reason was that clinical specimens did not cover all fifteen target bacteria, especially atypical pathogens, which are difficult to culture. These 5 bacterial species may not have been found in these specimens because the 157 clinical specimens came from the intensive care unit for Pulmonary and Critical Care Medicine. The 5 species were Mycoplasma pneumoniae, Haemophilus influenzae, Enterobacter cloacae, Legionella pneumophila, and Chlamydia pneumoniae, most of which are difficult to culture. Our DNA microarray would present obvious advantages in detecting these bacteria.

One of the weaknesses of this microarray is that it cannot differentiate between colonization and infection, similar to many other molecular amplification tests. Although some reports have indicated that the quantitative detection of pathogenic bacteria could help to distinguish colonization from infection [8,34], a meta-analysis showed that clinical outcomes were similar regardless of whether cultures were performed quantitatively or semiquantitatively [35]. Therefore, the identification of the causative agents of infections in patients with pneumonia remains a challenge for clinical microbiology laboratories. Nevertheless, taking the shortened turn-around time and the high throughput of this technique into account, this assay can be concluded to be superior to culture methods.

\section{Conclusions}

In conclusion, this DNA microarray for detecting important bacterial causes of pneumonia has the potential to be used as a faster diagnostic tool than current standard methods. Accurate and timely identification directly from clinical specimens should improve patient management and prevent inappropriate antibiotic therapy. 
Table 3 Identification results by microarray and bacterial culture of 157 clinical specimens

\begin{tabular}{|c|c|c|c|}
\hline Hybridzation report & Number (\%) & Microarray result & Standard culture \\
\hline \multirow[t]{11}{*}{ Correct identification } & $81(39.9)$ & Acinetobacter baumannii & Acinetobacter baumannii \\
\hline & $29(14.3)$ & Pseudomonas aeruginosa & Pseudomonas aeruginosa \\
\hline & $11(5.4)$ & Staphylococcus aureus & Staphylococcus aureus \\
\hline & $11(5.4)$ & Klebsiella pneumoniae & Klebsiella pneumoniae \\
\hline & $6(3.0)$ & Enterococcus faecium & Enterococcus faecium \\
\hline & $5(2.5)$ & Stenotrophomonas maltophilia & Stenotrophomonas maltophilia \\
\hline & $4(2.0)$ & Escherichia coli & Escherichia coli \\
\hline & $2(1.0)$ & Burkholderia cepacia & Burkholderia cepacia \\
\hline & $1(0.5)$ & Enterococcus faecalis & Enterococcus faecalis \\
\hline & $1(0.5)$ & Streptococcus pneumoniae & Streptococcus pneumoniae \\
\hline & $11(5.4)$ & Negative & Negative \\
\hline \multicolumn{4}{|l|}{ Incorrect identification } \\
\hline Pathogens belong to our target & $1(0.5)$ & Negative & Staphylococcus aureus \\
\hline \multirow[t]{9}{*}{ Pathogens not belong to our target } & $29(14.3)$ & Negative & Streptococcus viridans \\
\hline & $3(1.5)$ & Negative & Neisseria mucosa \\
\hline & $2(1.0)$ & Negative & Staphylococcus hominis \\
\hline & $2(1.0)$ & Negative & Staphylococcus epidermidis \\
\hline & $1(0.5)$ & Negative & Staphylococcus haemolyticus \\
\hline & $1(0.5)$ & Negative & Chryseobacterium indologenes \\
\hline & $1(0.5)$ & Negative & Ralstonia mannitolilytica \\
\hline & $1(0.5)$ & Negative & Citrobacter freundii \\
\hline & Total: 203 & & \\
\hline
\end{tabular}

\section{Methods}

\section{Study design}

First, we designed and evaluated the primers and probes for the target genes and fabricated the microarray. Second, the detection limit of this microarray was evaluated by using a series of 10 -fold dilutions $\left(10^{1}\right.$ copies $/ \mu \mathrm{L}$ to $10^{6}$ copies $\left./ \mu \mathrm{L}\right)$ of recombinant plasmids. Third, the accuracy of this microarray was evaluated by using genomic DNA from 19 standard strains and 123 clinical isolates (Table 2). Subsequently, 8 mixtures with two or three of these genomic DNAs were randomly mixed and used as templates to assess the ability of this microarray to distinguish mixed pathogens. Finally, the sensitivity and specificity of the microarray were evaluated with clinical samples. Spontaneous sputum specimens, endotracheal sputum aspirate specimens and bronchoalveolar lavage fluid (BALF) specimens were collected in our Pulmonary and Critical Care Medicine department. At the same time, the culture and identification of pathogens were performed in a blinded manner in the Department of Microbiology in our hospital. Direct DNA sequencing was used to confirm the results when they were discordant.

\section{Specimen collection and processing}

The 19 standard strain DNA samples and the 123 clinical isolates used in this study were obtained from the Beijing Institute of Radiation Medicine and Chinese PLA General Hospital (Table 2). All 142 bacterial strains were cultured overnight in $5 \mathrm{ml}$ of species-specific culture medium at the corresponding growth temperature. Genomic DNA of the cells was extracted by boiling with the same volume of lysate buffer $(25 \mathrm{mmol} / \mathrm{L} \mathrm{NaOH}, 0.1 \mathrm{nmol} / \mathrm{L}$ EDTA, 10 $\mathrm{mmol} / \mathrm{L}$ Tris- $\mathrm{HCl}, 1 \% \mathrm{NP} 40,2 \%$ Chelex-100, $1 \%$ Triton $\mathrm{X}-100$ ) for $10 \mathrm{~min}$, followed by centrifugation for $2 \mathrm{~min}$ at $12000 \mathrm{rpm}$, absorption of the supernatant and storage at $-70^{\circ} \mathrm{C}$ for testing [36]. $16 \mathrm{~S}$ rDNA was used as a control in the multiplex PCR assay to ensure the standardization and adequacy of the DNA templates from bacteria.

The 157 participating patients with clinically and radiologically confirmed pneumonia came from the intensive care unit of Pulmonary and Critical Care Medicine. All 36 spontaneous sputum specimens, 98 endotracheal sputum aspirate specimens, and 23 bronchoalveolar lavage fluid (BALF) specimens were collected between July 2013 and October 2014. All the specimens were immediately stored at $-70^{\circ} \mathrm{C}$ for DNA extraction. At the same time, the culture and 
identification of the pathogens were performed in a blinded manner at the Department of Microbiology in our hospital. Sputum samples were inoculated onto blood agar plates, chocolate agar plates and MacConkey agar plates using standard techniques and incubated at $37^{\circ} \mathrm{C}$ under $5 \%$ carbon dioxide in air for $18-24 \mathrm{~h}$. Then, the isolates were identified according to colonial morphology, standard biochemical methods, VITEK-2 analysis (bioMérieux), or matrix-assisted laser desorption ionization-time of flight mass spectrometry. All serum samples were collected and immediately refrigerated at $4{ }^{\circ} \mathrm{C}$ for immunoglobulin $\mathrm{M}$ antibody assays of $\mathrm{Myco-}$ plasma pneumoniae, Legionella pneumophila, and Chlamydia pneumoniae. An immunoglobulin $\mathrm{M}$ antibody detection kit (VIRCELL, Granada, Granada, Spain) was used according to the manufacturer's instructions, and the results were read under a EUROStar II immunofluorescence microscope (EUROIMMUN, Hanseatic City of Lubeck, Schleswig-Holstein, Germany).

The genomic DNA of the 157 clinical specimens was extracted via the following protocol: $30 \mathrm{~min}$ of liquefaction with $4 \% \mathrm{NaOH}, 10 \mathrm{~min}$ of boiling of $50 \mu \mathrm{l}$ of the liquefied specimens with $50 \mu \mathrm{l}$ of lysate buffer $(25 \mathrm{mmol} / \mathrm{L} \mathrm{NaOH}$, $0.1 \mathrm{nmol} / \mathrm{L}$ EDTA, $10 \mathrm{mmol} / \mathrm{L}$ Tris- $\mathrm{HCl}, 1 \% \mathrm{NP} 40,2 \%$ Chelex-100, 1\% Triton X-100), 2 min of waiting after addition to the DNA adsorption column, 1 min of centrifugation at 12,000 rpm, washing 2 times with $600 \mu \mathrm{l}$ of $75 \%$ alcohol, and elution in $50 \mu \mathrm{l}$ of $\mathrm{dd}_{2} \mathrm{O}$ [36]. All genomic DNAs were stored at $-70^{\circ} \mathrm{C}$ until use. We used $10 \mathrm{ng}$ of each DNA template in the multiplex PCR assays to ensure the adequacy of the DNA templates. Additionally, 16S rDNA was included in the multiplex PCR assays as a control to ensure the standardization and adequacy of the DNA templates.

\section{Construction of reference plasmids}

The standard strain DNAs listed in Table 1 were used to construct the reference plasmids. Plasmids containing the target genes were generated by cloning the PCR products with the pMD18 ${ }^{\mathrm{m}-\mathrm{T}}$-T vector system (TaKaRa, Shiga, Japan). All plasmids were defined by sequencing. Plasmid extracts were diluted in $\mathrm{ddH}_{2} \mathrm{O}$ to $10^{6}$ copies/ $\mu \mathrm{L}$ in a tenfold dilution series for use in microarray optimization.

\section{Primer and probe design and evaluation}

We selected both $16 \mathrm{~S}$ rDNA and 15 bacterial-specific genes as target genes to identify bacteria at the species level. The 15 bacterial-specific genes were lytA of Streptococcus pneumoniae, nuc of Staphylococcus aureus, P6 of Haemophilus influenzae, phoA of Escherichia coli, mdh of Klebsiella pneumoniae, toxA of Pseudomonas aeruginosa, gltA of Acinetobacter baumannii, P1 of Mycoplasma pneumoniae, ddl of Enterococcus faecalis and Enterococcus faecium, dnaJ of Enterobacter cloacae, chitA of
Stenotrophomonas maltophilia, recA of Burkholderia cepacia, mip of Legionella pneumophila and ompA of Chlamydia pneumoniae. All gene sequences were downloaded from NCBI (http://www.ncbi.nlm.nih.gov/genomes). A pair of universal primers was designed to amplify specific sequences in conserved upstream and downstream regions of the $16 \mathrm{~S}$ rDNA sequence. In the variable regions between universal primers, specific probes and a positive control probe were designed. Klebsiella pneumoniae, Enterobacter cloacae and Escherichia coli were detected with the same specific probe because of their highly similar sequences. For the 15 bacterial-specific genes, we designed the primers and probes using DNAMAN 6 and Oligo 7 software, respectively. Primers were selected in conserved upstream or downstream regions, and probes were designed in the variable portion of the sequences. All primer and probe sequences were aligned using BLAST (http://blast.ncbi.nlm.nih.gov/) to compare the homology between potential targets belonging to the same genus. To evaluate the efficiency of all primers, reference genomic DNAs of the 15 bacterial species were amplified and examined by $2 \%$ agarose gel electrophoresis. All primers and probes were finally confirmed by the sequence analysis of the PCR products from the reference plasmids.

\section{Microarray preparation}

This DNA microarray was designed to contain 32 probes, including 1 universal $16 \mathrm{~S}$ rDNA probe and 3 negative control probes, in eight columns and eight rows. The universal 16S rDNA probe was used to detect whether the samples contained bacteria. The probes were synthesized by Sangon Biotech Co., Ltd. (Shanghai). Each probe (50 $\mu \mathrm{M}$ final concentration) was spotted twice repeatedly with a noncontact Nanoplotter 2.1 inkjet (GeSim, Dresden, Germany) onto the aldehyde chip after mixing with uniform proportional printing buffer (5\% glycerol, $0.1 \%$ sodium dodecyl sulphate (SDS), 6x saline sodium citrate buffer (SSC), and $2 \%$ (wt/vol) Ficoll 400). The microarray layout is shown in Fig. 1a. Microarrays were prepared as previously described by our research group [37].

\section{Multiplex asymmetric PCR}

The primers for $16 \mathrm{~S}$ rDNA and the 15 specific genes were divided into three groups for multiplex asymmetric PCR. Reactions were carried out on a Veritil 96-well Thermal Cycler instrument (Applied Biosystems by Life Technologies, Singapore). The final reaction volume for each multiplex asymmetric PCR assay was $25 \mu$, including the same Multiplex PCR $5 \times$ Master Mix reagents ( $5 \mu \mathrm{l}$, New England Biolabs, UK) and amount of DNA template $(2.5 \mu \mathrm{l})$. The forward and reverse primer concentrations for $16 \mathrm{~S} \mathrm{rDNA}$, P6 and mip were $0.08 \mu \mathrm{M}$ 
and $0.4 \mu \mathrm{M}$, respectively. For the other targets, these concentrations were $0.16 \mu \mathrm{M}$ and $0.8 \mu \mathrm{M}$, respectively. The cycling parameters were optimized as follows: 10 min at $95^{\circ} \mathrm{C} ; 35$ cycles of $30 \mathrm{~s}$ at $95^{\circ} \mathrm{C}, 30 \mathrm{~s}$ at $55^{\circ} \mathrm{C}$, and $1 \mathrm{~min}$ at $68^{\circ} \mathrm{C}$; and a final extension of $5 \mathrm{~min}$ at $68^{\circ} \mathrm{C}$.

\section{Hybridization and signal detection}

Prior to hybridization, the PCR products were denatured at $98^{\circ} \mathrm{C}$ for $5 \mathrm{~min}$ and chilled on ice. A $2.5 \mu \mathrm{l}$ aliquot of each amplification product from the three multiplex PCR assays was mixed with $7.5 \mu \mathrm{l}$ of hybridization buffer $(0.6 \%$ SDS, $10 \%$ formylamine, $8 \times$ SSC, and $10 \times$ Denhardt). A total of $15 \mu \mathrm{l}$ of the hybridization mixture was reacted with the probes at $45^{\circ} \mathrm{C}$ for $1 \mathrm{~h}$. Thereafter, the slide was washed for $1 \mathrm{~min}$ each with washing buffer A $(1 \times$ SSC and $0.2 \%$ SDS $)$, washing buffer $B(0.2 \times$ SSC), and washing buffer C $(0.1 \times$ SSC) for and then dried by centrifugation. Subsequently, 1:1500-diluted streptavidin-horseradish peroxidase (HRP) was incubated in each reaction chamber on the chip for $30 \mathrm{~min}$ at $37^{\circ} \mathrm{C}$, and the slide was washed once with PBST (0.05\% Tween 20) for 1 min and dried by centrifugation. Finally, the regions of hybridization on the slide were covered with $20 \mu \mathrm{l}$ phospho-tyrosine (Millipore, USA), and the signal was immediately detected with a portable biochip chemiluminescence imaging instrument (Academy of Military Medical Sciences, China).

\section{Supplementary information}

Supplementary information accompanies this paper at https://doi.org/10. 1186/s12866-020-01842-3.

Additional file 1: Figure S1. PCR products examined by $2 \%$ agarose gel electrophoresis. a, Agarose gel electrophoresis of PCR products amplified using the universal $16 \mathrm{~S}$ rDNA primer. DNA templates were extracted from: $1 \mathrm{ddH_{2 }}$ O; 2 Haemophilus influenzae (ATCC9007); 3 Haemophilus influenzae (ATCC33533); 4 Staphylococcus aureus; 5 Acinetobacter baumannii; 6 Escherichia coli; 7 Streptococcus pneumoniae; 8 Pseudomonas aeruginosa; 9 Chlamydia pneumoniae; 10 Mycoplasma pneumoniae; 11 Legionella pneumophila; 12 Klebsiella pneumoniae; 13 Enterococcus faecalis; 14 Enterococcus faecium; 15 Stenotrophomonas maltophilia; 16 Burkholderia cepacia; 17 Enterobacter cloacae; respectively. b. Agarose gel electrophoresis of PCR products amplified using 15 pairs of primers for the 15 bacterial specific genes. The 15 bacterial specific genes were 1 P1; 2 ddl (for Enterococcus faecalis); 3 dnaJ; 4 mdh; 5 chitA; 6 lytA; 7 recA; 8 phoA; 9 dd ${ }_{2} \mathrm{O} ; 10$ ddl (for Enterococcus faecium); $11 \mathrm{gltA} ; 12$ mip; 13 nuc; 14 toxA; 15 ompA; 16 P6, respectively.

\section{Abbreviations \\ PCR: Polymerase chain reaction; rDNA: Ribosomal DNA; ATCC: American Type Culture Collection; CMCC: National Center for Medical Culture Collections; CGMCC: China General Microbiological Culture Collection Center; \\ CAP: Community acquired pneumonia; HAP: Hospital acquired pneumonia; BALF: Bronchoalveolar lavage fluid; SDS: Sodium dodecyl sulfate; \\ SCC: Salinesodium citrate buffer; HRP: Streptavidin-horseradish peroxidase}

\section{Acknowledgements}

We thank our colleagues in Chinese PLA General Hospital who provided preservation and recovery of bacteria strains, Prof. Shengqi Wang and the staff in Beijing Institute of Radiation Medicine who provided technical help.

\section{Authors' contributions}

LAC and QQL designed the study, analyzed the data and proofread the manuscript. XQM was responsible for experiment performance and manuscript drafting. YQL helped with analyzed the data. YL1, YL2 and LY collected samples. CSL revised the manuscript and provided part of experimental materials. All authors read and approved the final manuscript.

\section{Funding}

Not applicable.

\section{Availability of data and materials}

The data used and analysed for the current study are available upon request from the first author Xiuqing Ma (E-mail: mxq820812@163.com).

\section{Ethics approval and consent to participate}

This study was approved by the Ethics Committee of Chinese PLA General Hospital (No. S2014-049-01). All experiments were conducted in accordance with the relevant guidelines and regulations. All patients involved in the study provided written informed consent and all personal information was kept confidential.

\section{Consent for publication}

Not applicable.

\section{Competing interests}

The authors declare that they have no competing interests.

\section{Author details}

${ }^{1}$ Department of Pulmonary \& Critical Care Medicine, Chinese PLA General Hospital, Beijing, China. ${ }^{2}$ Department of Biotechnology, Beijing Institute of Radiation Medicine, Beijing, China.

Received: 11 February 2020 Accepted: 3 June 2020

Published online: 23 June 2020

\section{References}

1. Eccles S, Pincus C, Higgins B, Woodhead M; Guideline Development Group Diagnosis and management of community and hospital acquired pneumonia in adults: summary of NICE guidance BMJ 2014, 349: g6722. https://doi.org/10.1136/bmj.g6722.

2. Reddington K, Tuite N, Barry T, O'Grady J, Zumla A. Advances in multiparametric molecular diagnostics technologies for respiratory tract infections. Curr Opin Pulm Med 2013;19(3):298-304. https://doi.org/10.1097/ MCP.0b013e32835f1b32.

3. Harris M, Clark J, Coote N, Fletcher P, Harnden A, McKean M, et al. British Thoracic Society guidelines for the management of community acquired pneumonia in children: update 2011. Thorax. 2011;66(Suppl 2):ii1-ii23. http:// dx.doi.org/10.1136/thoraxjnl-2011-200598.

4. Song KP, Chan TK, Ji ZL, Wong SW. Rapid identification of Pseudomonas aeruginosa form ocular isolates by PCR using exotoxin A-specific parimers. Mol Cell Probes 2000;14(4):199-204. http://dx.doi.org/10.1006/mcpr.2000. 0306.

5. Ginevra C, Barranger C, Ros A, Mory O, Stephan JL, Freymuth F, et al. Development and evaluation of Chlamylege, a new commercial test allowing simultaneous detection and identification of Legionella, Chlamydophila pneumoniae, and mycoplasma pneumoniae in clinical respiratory specimens by multiplex PCR. J Clin Microbiol 2005;43(7):32473254. http://dx.doi.org/10.1128/jcm.43.7.3247-3254.2005.

6. Abdeldaim GM, Herrmann B. PCR detection of Haemophilus influenzae from respiratory specimens. Methods Mol Biol 2013;943:115-123. http://dx.doi. org/10.1007/978-1-60327-353-4_7.

7. Espy MJ, Uhl JR, Sloam LM, Buckwalter SP, Jones MF, Vetter EA, et al. Realtime PCR in clinical microbiology: applications for routine laboratory testing. Clin Microbiol Rev 2006;19(1):165-256. http://dx.doi.org/10.1128/CMR.19.1. 165-256.2006.

8. Gadsby NJ, McHugh MP, Russell CD, Mark H, Conway Morris A, Laurenson IF, et al. Development of two real-time multiplex PCR assays for the detection and quantification of eight key bacterial pathogens in lower respiratory tract infections. Clin Microbiol Infect. 2015;21(8):788.e1-788.e13. https://doi. org/10.1016/j.cmi.2015.05.004. 
9. Rampini SK, Bloemberg GV, Keller PM, Büchler AC, Dollenmaier G, Speck RF, et al. Broad-range $16 \mathrm{~S}$ rRNA gene polymerase chain reaction for diagnosis of culture-negative bacterial infections. Clin Infect Dis 2011;53(12):12451251. https://doi.org/10.1093/cid/cir692.

10. Kim CM, Song ES, Jang HJ, Kim HJ, Lee S, Shin JH, et al. Development and evaluation of oligonucleotide chip based on the 16S-23S rRNA gene spacer region for detection of pathogenic microorganisms associated with sepsis. J Clin Microbiol 2000;48(5):1578-1583. https://doi.org/10.1128/JCM.01130-09.

11. Rantakokko-Jalava K, Nikkari S, Jalava J, Eerola E, Skurnik M, Meurman O, et al. Direct amplification of rRNA genes in diagnosis of bacterial infections. J Clin Microbiol. 2000;38(1):32-9 https://pubmed.ncbi.nlm.nih.gov/10618059/.

12. Mignard S, Flandrois JP. $16 \mathrm{~S}$ rRNA sequencing in routine bacterial identification: a 30-month experiment. J Microbiol Methods 2006;67(3):574581. https://doi.org/10.1016/j.mimet.2006.05.009.

13. Zhang W, Chen C, Cui J, Bai W, Zhou J. Application of loop-mediated isothermal (LAMP) assay for the rapid diagnosis of pathogenic bacteria in clinical sputum specimens of acute exacerbation of COPD (AECOPD). Int J Clin Exp Med. 2015;8(5):7881-9 https://pubmed.ncbi.nlm.nih.gov/26221344/.

14. Thong KL, Lai MY, Teh CSJ, Chua KH. Simultaneous detection of methicillinresistant Staphylococcus aureus, Acinetobacter baumannii, Escherichia coli, Klebsiella pneumoniae and Pseudomonas aeruginosa by multiplex PCR. Trop Biomed. 2011;28(1):21-31 https://pubmed.ncbi.nlm.nih.gov/21602765/.

15. Yean CY, Yin LS, Lalitha P, Ravichandran M. A nanoplex PCR assay for the rapid detection of vancomycin and bifunctional aminoglycoside resistance genes in Enterococcus species. BMC Microbiol, 2007, 11;7:112. https://doi. org/10.1186/1471-2180-7-112.

16. Pavlovic M, Konrad R, Iwobi AN, Sing A, Busch U, Huber I. A dual approach employing MALDI-TOF MS and real-time PCR for fast species identification within the Enterobacter cloacae complex. FEMS Microbiol Lett, 2012,328(1): 46-53. https://doi.org/10.1111/j.1574-6968.2011.02479.x.

17. Cretoiu MS, Berini F, Kielak AM, Marinelli F, van Elsas JD. A novel salt-tolerant chitobiosidase discovered by genetic screening of a metagenomic library derived from chitin-amended agricultural soil. Appl Microbiol Biotechnol 2015,99(19):8199-8215. https://doi.org/10.1007/s00253-015-6639-5.

18. Dalmastri C, Pirone L, Tabacchioni S, Bevivino A, Chiarini L. Efficacy of species-specific recA PCR tests in the identification of Burkholderia cepacia complex environmental isolates. FEMS Microbiol Lett 2005;246(1):39-45. https://doi.org/10.1016/j.femsle.2005.03.041.

19. Morio F, Corvec S, Caroff N, Le Gallou F, Drugeon H, Reynaud A. Real-time PCR assay for the detection and quantification of Legionella pneumophila in environmental water samples: utility for daily practice. Int J Hyg Environ Health, 2008, 211(3-4):403-411. https://doi.org/10.1016/j.ijheh.2007.06.002.

20. Curran T, Coulter WA, Fairley DJ, McManus T, Kidney J, Larkin M, Moore JE, Coyle PV. Development of a novel DNA microarray to detect bacterial pathogens in patients with chronic obstructive pulmonary disease (COPD). J Microbiol Methods 2010;80(3):257-261. https://doi.org/10.1016/j.mimet.2010. 01.004 .

21. S Burteau, P Bogaerts, R de Mendonça, L Irenge, C Berhin, J Hiffe, N de San, P Beyne, S Hamels, Y Glupczynski, M Struelens, J-L Gala, J Remacle. Design and validation of a low density Array (Nosochip) for the detection and identification of the Main pathogenic Bacteria and Fungi responsible for nosocomial pneumonia. Eur J Clin Microbiol Infect Dis, 2008;27 (1), 17-27. https://doi.org/10.1007/s10096-007-0394-1.

22. Roth SB, Jalava J, Ruuskanen O, Ruohola A, Nikkari S. Use of an oligonucleotide array for laboratory diagnosis of bacteria responsible for acute upper respiratory infections. J Clin Microbiol 2004,42(9):4268-4274. https://doi.org/10.1128/JCM.42.9.4268-4274.2004.

23. Zhao C, Chen H, Wang H, Liu W, Zhuo C, Chu Y, et al. Analysis of pathogen spectrum and resistance of clinical common organisms causing bloodstream infections, hospital-acquired pneumonia and intraabdominal infections from thirteen teaching hospitals in 2013. Zhonghua Yi Xue Za Zhi 2015, 95(22):1739-1746. https://doi.org/10. 3760/cma.j.issn.0376-2491.2015.22.008.

24. Mandell LA, Wunderink RG, Anzueto A, Bartlett JG, Campbell GD, Dean NC, et al. Infectious Diseases Society of America/American Thoracic Society consensus guidelines on the management of community-acquired pneumonia in adults. Clin Ifect Dis. 2007, Suppl 2:S27-72. https://doi.org/10. $1086 / 511159$.

25. Loens K, Beck T, Ursi D, Overdijk M, Sillekens P, Goossens H, et al. Evaluation of different nucleic acid amplification techniques for the detection of $\mathrm{M}$. pneumoniae, C. pneumoniae and Legionella spp. in respiratory specimens from patients with community-acquire pneumonia. J Microbiol Methods 2008,73(3):257-262. https://doi.org/10.1016/j.mimet.2008.02.010.

26. Thurman KA, Warner AK, Cowart KC, Benitez AJ, Winchell JM. Detection of mycoplasma pneumoniae, chlamydia pneumoniae, and Legionella spp. in clinical specimens using a single-tube multiplex real-time PCR assay. Diagn Microbio Infect Dis 2011,70(1):1-9. https://doi.org/10.1016/j.diagmicrobio.2010.11.014.

27. Waterer GW, Jennings SG, Wunderink RG. The impact of blood cultures on antibiotic therapy in pneumococcal pneumonia. Chest. 1999, 116(5):12781281. https://doi.org/10.1378/chest.116.5.1278.

28. Kalil AC, Metersky ML, Klompas M, Muscedere J, Sweeney DA, Palmer LB, et al. Management of Adults with Hospital-acquired and Ventilatorassociated Pneumonia: 2016 clinical practice guidelines by the Infectious Diseases Society of America and the American Thoracic Society. Clin Infect Dis 2016,63(5):e61-e111. https://doi.org/10.1093/cid/ciw353.

29. Tenover FC. Developing molecular amplification methods for rapid diagnosis of respiratory tract infections caused by bacterial pathogens. Clin Infect Dis 2011,52 Suppl 4:S338-S345. https://doi.org/10.1093/cid/cir049.

30. Leski TA, Lin B, Malanoski AP, Stenger DA. Application of resequencing microarrays in microbial detection and characterization. Future Microbiol 2012,7(5): 625-637. https://doi.org/10.2217/fmb.12.30.

31. van der Zee A, Roorda L, Bosman G, Ossewaarde JM. Molecular diagnosis of urinary tract infections by semi-quantitative detection of uropathogens in a routine clinical hospital setting. PLoS One 2016, 11(3):e0150755. https://doi. org/10.1371/journal.pone.0150755.

32. Park SD, Lee G, Wang HY, Park M, Kim S, Kim H, et al. Evaluation of PCRreverse blot hybridization assay, REBA sepsis-ID test, for simultaneous identification of bacterial pathogens and mecA and van genes from blood culture bottles. Ann Lab Med 2014, 34(6):446-455. https://doi.org/10.3343/ alm.2014.34.6.446.

33. Ryan Tewhey, Christopher R Cannavino, John AD Leake, Vikas Bansal, Eric J Topol, Ali Torkamani, et al. Genetic structure of community acquired methicillin-resistant Staphylococcus aureus USA300. BMC Genomics. 2012, 13: 508. https://doi.org/10.1186/1471-2164-13-508.

34. Sanchez-Nieto JM, Torres A, Garcia-Cordoba F, El-Ebiary M, Carrillo A, Ruiz J, et al. Impact of invasive and noninvasive quantitative culture sampling on outcome of ventilator-associated pneumonia: a pilot study. Am J Respir Crit Care Med 1998, 157(2):371-376. https://doi.org/10.1164/ajrccm.157.2.97-02039.

35. Berton DC, Kalil AC, Teixeira PJ. Quantitative versus qualitative culture of respiratory secretions for clinical outcomes in patients with ventilatorassociated pneumonia. Cochrane Database Syst Rev 2014,30 (10):CD006482. https://doi.org/10.1002/14651858.CD006482.pub4.

36. Walsh PS, Metzger DA, Higuchi R. Chelex 100 as a medium for simple extraction of DNA for PCR-based typing from forensic material. Biotechniques. 1991;10(4):506-13 https://pubmed.ncbi.nlm.nih.gov/1867860/.

37. Song Y, Dou F, Zhou Z, Yang N, Zhong J, Pan J, Liu Q, Zhang J, Wang S. Microarray-based detection and clinical evaluation for helicobacter pylori resistance to clarithromycin or levofloxacin and the genotype of CYP2C19 in 1083 patients. Biomed Res Int 2018:2684836. https://doi.org/10.1155/ $2018 / 2684836$.

\section{Publisher's Note}

Springer Nature remains neutral with regard to jurisdictional claims in published maps and institutional affiliations.

Ready to submit your research? Choose BMC and benefit from:

- fast, convenient online submission

- thorough peer review by experienced researchers in your field

- rapid publication on acceptance

- support for research data, including large and complex data types

- gold Open Access which fosters wider collaboration and increased citations

- maximum visibility for your research: over $100 \mathrm{M}$ website views per year

At $\mathrm{BMC}$, research is always in progress.

Learn more biomedcentral.com/submissions 